\title{
Illness Perception and Medication Adherence Among Patients with Primary Hypothyroidism in Al Qassim, Saudi Arabia
}

This article was published in the following Dove Press journal: Patient Preference and Adherence

\author{
Omar Buraykan Alluhayyan $\mathbb{D}^{1}$ \\ Rakan Jaser Alsahly (D) $^{2}$ \\ Abdulrahman Abbas \\ Aldawsari $\mathbb{D}^{2}$ \\ Khaled Abdulrahman \\ Alghabawy \\ Rifal Saleh Alqaan' \\ Abeer Fahad Almutairi' \\ Saleh Ali Alharbi ${ }^{3}$ \\ 'College of Medicine, Qassim University, \\ Al Qassim, Saudi Arabia; ${ }^{2}$ College of \\ Medicine, Majmaah University, Majmaah, \\ Saudi Arabia; ${ }^{3}$ Department of Family and \\ Community Medicine, King Saud \\ Hospital, Al Qassim, Saudi Arabia
}

Correspondence: Omar Buraykan Alluhayyan

Qassim University, Al Qassim, Saudi Arabia Tel +966594474I77

Email 35III4266@qu.edu.sa

\begin{abstract}
Purpose: Poor adherence to levothyroxine is a potential risk factor for treatment failure that ultimately leads to increased healthcare costs and serious health outcomes. This study aimed to investigate the correlation between illness perception and medication adherence among primary hypothyroidism patients.
\end{abstract}

Patients and Methods: We conducted a cross-sectional survey among primary hypothyroidism patients who met the inclusion criteria in the Qassim region of Saudi Arabia using a questionnaire with demographic characteristics, clinical factors, the 12-Item Medication Adherence Scale, and the Brief Illness Perception Questionnaire (BIPQ). We included 400 patients in the analysis.

Results: We found a significant positive correlation between BIPQ subscales - personal control, treatment control, and understanding - with all domains of the 12-Item Medication Adherence Scale. The other dimensions of BIPQ subscales did not significantly correlate with medication adherence. However, a high BIPQ overall score was significantly correlated with poor medication adherence.

Conclusion: This study found a significant correlation between a high BIPQ overall score and poor medication adherence. This finding suggests the need to consider the emotional and cognitive representation of hypothyroidism in hypothyroid patients to improve their treatment adherence.

Keywords: hypothyroidism, levothyroxine, medication adherence, illness perception

\section{Introduction}

Hypothyroidism is one of the most common conditions in endocrinology clinics. ${ }^{1}$ Globally, the prevalence of spontaneous primary hypothyroidism is between $1 \%$ and $2 \%{ }^{2}$ In Saudi Arabia, the prevalence of hypothyroidism among patients in primary health centers is $29.1 \%{ }^{3}$ Oral levothyroxine has been shown to control the illness significantly in most patients with hypothyroidism. ${ }^{4}$ Adherence is defined by the World Health Organization as "the extent to which the patient follows medical instructions". 5 Briesacher et al report that $31.6 \%$ of patients with hypothyroidism did not adhere to the prescribed medications. ${ }^{6}$ A prior study shows that adherence was seen in $51.3 \%$ of patients on levothyroxine for hypothyroidism. ${ }^{7}$ Crilly and Esmail report that the adherence rate to medication in patients with hypothyroidism is $78 \%{ }^{8}$

Poor adherence to levothyroxine can cause treatment failure that ultimately leads to increased healthcare costs and serious health outcomes. ${ }^{9}$ Many factors can contribute to non-adherence to medication. Medication safety, necessity, and affordability can influence the patient's decision to take the medication as prescribed. ${ }^{10}$ Age of the patient 
(young patient) visiting the physician and having information about the illness from the physician can significantly increase adherence among hypothyroid patients. Conversely, having comorbidity besides hypothyroidism and canceling medical appointments can significantly decrease adherence. ${ }^{11}$ Several intervention trials found that when the patients believe that the medication is effective, there is better adherence. Besides several other factors, illness perception is one of the greatest predictors of medication compliance. ${ }^{12}$ Illness perceptions are adjustable factors and can affect medication adherence in patients with chronic disease. A prior study in hypertensive patients found that those patients with more positive illness perceptions had better drug adherence and patients with negative illness perceptions with strong confidence in treatment control had worse adherence. ${ }^{13}$ Under the influence of illness perception, the patient will try to act as per the situation. This action may be positive- seeking medical adviceor negative- stop the medication. ${ }^{14}$ Adherence to hypothyroidism treatment has a profound impact on the patient's disease course and outcome. To the best of our knowledge, there has been no study to assess the relationship between medication adherence and illness perception among hypothyroid patients. Furthermore, medication adherence and illness perception in hypothyroid patients in Saudi Arabia has been recognized as a major research gap in the literature. Therefore, the primary aim of this study was to determine the level of illness perception, adherence to medication, and their correlation in primary hypothyroidism patients.

\section{Patients and Methods}

\section{Study Design, Setting, and Participants}

This observational cross-sectional study was conducted in the Qassim region of Saudi Arabia. The questionnaire was distributed among patients with hypothyroidism in the outpatient endocrine clinics of the King Saud Hospital. Also, an electronic self-administered survey was sent specifically to patients with hypothyroidism through social media. The sample size was calculated using the proportion of medication adherence (51.3\%) reported in a previous study with 5\% confidence limits and 5\% degree of precision. ${ }^{7}$ The minimum sample size calculated for the present study was 400 after adding 4\% non-response rate. This study included patients who were aged $>18$ years and were on outpatient levothyroxine treatment for hypothyroidism in the clinic for at least 3 months. Any patients with thyroid cancer, central or transient hypothyroidism, newly diagnosed primary hypothyroidism, neck irradiation, radioiodine ablation, mental illness, or dementia were excluded from our study.

\section{Data Collection Methods}

The data were collected using a validated and selfadministrated questionnaire in the Arabic language. Questionnaire items (see supplement) included demographic characteristics (gender, age, height, weight, body mass index [BMI], exercise) and clinical factors (comorbidities, disease duration, regular follow-up, received education about hypothyroidism, easy access to a physician, duration of visit, following physician's instructions, place of taking medication).

\section{The 12-Item Medication Adherence Scale}

Medication adherence was measured using the 12-Item Medication Adherence scale. The validated Arabic version of the 12-Item Medication Adherence scale was obtained with permission. ${ }^{15}$ The scale has four dimensions: treatment compliance, collaboration with healthcare providers, willingness to access and use information about treatment and acceptance to take treatment, and how taking treatment fits patients' lifestyles. Each dimension is composed of three items rated on a five-point Likert scale $(1=$ never to $5=$ always). The total summed score ranged from $0-60$ and a higher score indicated better medication adherence.

\section{Assessment of Illness Perceptions Questionnaire (BIPQ)}

Illness perception was evaluated by the Arabic version of the BIPQ. ${ }^{16}$ The BIPQ included nine items: consequences, timeline, personal control, treatment control, identity, concerns, understanding, and emotional response. The last dimension (item 9) is an open-ended question that assesses the patients' beliefs about the causes of their disease and was omitted from our study. The overall BIPQ score was calculated after summing the scores for each item. A higher score indicated a higher intimidating illness perception.

\section{Data Analysis}

All statistical analysis was completed using IBM SPSS Statistics Version 25. The characteristics of the sample were described by mean \pm standard deviation (SD) or percentage. The mean value of the adherence score was compared across certain sociodemographic and clinical variables, using $t$-test and one-way ANOVA. The correlation between medication adherence and illness perception 
was analyzed by Spearman's rank correlation coefficient. Stepwise multiple linear regression analyses were conducted to test the determinants of the adherence score. A p-value $<0.05$ was considered statistically significant.

\section{Ethical Consideration}

The present study was approved by the regional bioethical committee of the Qassim region.

Informed consent was obtained from each patient to participate in our study. Investigators were ascertained enough protections to respect and safeguard the privacy of the research patients throughout the study.

\section{Results}

The patients' characteristics and clinical information are presented in Table 1. Most of the patients were female (80.5\%) and aged 18-40 years (68.5\%). Almost half of the patients were obese and had no comorbidities. More than $60 \%$ of the patients did not exercise, have received hypothyroidism education and had hypothyroidism for 1-5 years. Regular followup and adherence to the physician's instructions were seen in $78.5 \%$ of patients. More than $80 \%$ of patients had easy access to their physician, got free medications from the clinic, and were satisfied with the visit duration.

\section{Assessment of Medication Adherence and Illness Perceptions}

Table 2 shows the mean score and SD of the BIPQ and the 12-Item Medication Adherence Scale. The total mean score of the 12-Item Medication Adherence Scale was $46.21 \pm 9.84$. There was a slight difference between the mean scores of the 12-Item Medication Adherence Scale. Collaboration and medication compliance had the highest and least score, respectively $(12.32 \pm 3.31$ vs $10.67 \pm$ 2.86). The overall mean score of the BIPQ items was $(41.40 \pm 13.41)$. Out of the eight items of BIPQ, timeline and treatment control had the highest and least score, respectively $(7.18 \pm 2.99$ vs $3.37 \pm 2.74)$.

The Cronbach's alpha coefficients of the 12-Item Medication Adherence Scale and BIPQ were 0.85 and 0.70 , respectively, indicating very good reliability.

\section{Correlation Between Medication Adherence and IIIness Perception}

We found a significant positive correlation between the BIPQ subscales- personal control, treatment control, and understanding- with all domains of the 12-Item
Table I The Patient Characteristics

\begin{tabular}{|c|c|c|c|}
\hline & & $n=400$ & $\%$ \\
\hline Age & $\begin{array}{l}18-40 \text { years } \\
4 I-59 \text { years } \\
60 \text { years and above }\end{array}$ & $\begin{array}{l}274 \\
95 \\
31\end{array}$ & $\begin{array}{l}68.5 \\
23.8 \\
7.8\end{array}$ \\
\hline Gender & $\begin{array}{l}\text { Male } \\
\text { Female }\end{array}$ & $\begin{array}{l}76 \\
322\end{array}$ & $\begin{array}{l}19 \\
80.5\end{array}$ \\
\hline BMI & $\begin{array}{l}\text { Normal } \\
\text { Overweight } \\
\text { Obese }\end{array}$ & $\begin{array}{l}63 \\
122 \\
197\end{array}$ & $\begin{array}{l}15.8 \\
30.5 \\
49.3\end{array}$ \\
\hline Do you exercise? & $\begin{array}{l}\text { Yes } \\
\text { No }\end{array}$ & $\begin{array}{l}149 \\
250\end{array}$ & $\begin{array}{l}37.3 \\
62.5\end{array}$ \\
\hline $\begin{array}{l}\text { Do you have any } \\
\text { comorbidities? }\end{array}$ & $\begin{array}{l}\text { Yes } \\
\text { No }\end{array}$ & $\begin{array}{l}161 \\
198\end{array}$ & $\begin{array}{l}40.3 \\
49.5\end{array}$ \\
\hline $\begin{array}{l}\text { Duration of } \\
\text { hypothyroidism }\end{array}$ & $\begin{array}{l}1-5 \text { years } \\
6-10 \text { years } \\
11 \text { years and above }\end{array}$ & $\begin{array}{l}225 \\
64 \\
33\end{array}$ & $\begin{array}{l}65.3 \\
16 \\
8.3\end{array}$ \\
\hline $\begin{array}{l}\text { Do you follow your } \\
\text { condition in the clinic on } \\
\text { a regular basis? }\end{array}$ & $\begin{array}{l}\text { Yes } \\
\text { No }\end{array}$ & $\begin{array}{l}314 \\
86\end{array}$ & $\begin{array}{l}78.5 \\
21.5\end{array}$ \\
\hline $\begin{array}{l}\text { Have you received an } \\
\text { education about } \\
\text { hypothyroidism? }\end{array}$ & $\begin{array}{l}\text { Yes } \\
\text { No }\end{array}$ & $\begin{array}{l}243 \\
157\end{array}$ & $\begin{array}{l}60.8 \\
39.3\end{array}$ \\
\hline $\begin{array}{l}\text { Do you access your } \\
\text { physician easily? }\end{array}$ & $\begin{array}{l}\text { Yes } \\
\text { No }\end{array}$ & $\begin{array}{l}341 \\
59\end{array}$ & $\begin{array}{l}85.3 \\
4.8\end{array}$ \\
\hline $\begin{array}{l}\text { Do you spend enough time } \\
\text { with your physician during } \\
\text { the visit? }\end{array}$ & $\begin{array}{l}\text { Yes } \\
\text { No }\end{array}$ & $\begin{array}{l}346 \\
52\end{array}$ & $\begin{array}{l}86.5 \\
13\end{array}$ \\
\hline $\begin{array}{l}\text { Do you follow your } \\
\text { physician's instructions? }\end{array}$ & $\begin{array}{l}\text { Yes } \\
\text { No }\end{array}$ & $\begin{array}{l}341 \\
85\end{array}$ & $\begin{array}{l}78.5 \\
21.3\end{array}$ \\
\hline $\begin{array}{l}\text { From where do you obtain } \\
\text { your medications? }\end{array}$ & $\begin{array}{l}\text { Free from the clinic } \\
\text { Bought from } \\
\text { pharmacies }\end{array}$ & $\begin{array}{l}341 \\
58\end{array}$ & $\begin{array}{l}85.3 \\
14.5\end{array}$ \\
\hline
\end{tabular}

Medication Adherence Scale (Table 3). The other dimensions of the BIPQ subscales did not correlate significantly with medication adherence. However, a higher BIPQ overall score was significantly correlated with poor medication adherence $[\mathrm{r}=-0.180, \mathrm{p}<0.01]$.

\section{Association of Medication Adherence Mean Score with Socio-Demographic and Clinical Factors}

The comparison of mean adherence scores with the sociodemographic characteristics of the patients showed significant 
Table 2 Mean Scores and Standard Deviations of BIPQ and 12-Item Medication Adherence Scales

\begin{tabular}{|c|c|c|c|}
\hline \multicolumn{4}{|c|}{ I2-Item Medication Adherence Scale } \\
\hline & Mean & Std. Deviation & $\mathbf{N}$ \\
\hline Medication compliance & 10.67 & 2.86 & 400 \\
\hline Collaboration & 12.32 & 3.31 & 399 \\
\hline Willingness & $|1.5|$ & 3.27 & 399 \\
\hline Acceptance & 11.70 & 2.78 & 400 \\
\hline Total & 46.21 & 9.84 & 399 \\
\hline \multicolumn{4}{|l|}{ BIPQ scale } \\
\hline & Mean & Std. Deviation & $\mathbf{N}$ \\
\hline Consequences & 5.25 & 2.91 & 400 \\
\hline Timeline & 7.18 & 2.99 & 399 \\
\hline Personal control & 4.10 & 2.68 & 400 \\
\hline Treatment control & 3.37 & 2.74 & 399 \\
\hline Identity & 5.93 & 2.71 & 400 \\
\hline Concerns & 5.80 & 3.33 & 400 \\
\hline Understanding & 3.64 & 2.73 & 400 \\
\hline Emotional response & 6.09 & 3.29 & 400 \\
\hline Total & 41.40 & $13.4 \mid$ & 398 \\
\hline
\end{tabular}

differences in female patients with higher adherence mean scores $(p<0.001)$ (Table 4). Scores of the young and middleaged patients were significantly higher than those of elderly patients $(p<0.01)$. Patients with previous hypothyroidism education had a higher mean adherence score vs patients with no hypothyroidism education $(p<0.001)$. Patients with easy access to their physician and enough time during the visit were more likely to have higher adherence mean scores $(\mathrm{p}<$ 0.0001). In addition, patients with regular follow-up in the clinic and to the physician's instructions had higher mean adherence scores $(p<0.0001)$. Comorbidity, exercise, BMI, duration of hypothyroidism, and the place of obtaining medications had no relation with adherence scores $(p>0.05)$.

\section{Multivariate Analysis of the Factors Associated with the Adherence Score}

Multiple stepwise linear regression was conducted to analyze the predictors of medication adherence. The total medication adherence score was the dependent variable, and the variables with a statistically significant correlation with the medication adherence score were used as independent variables. As shown in Table 5, following instructions, duration of visit, the BIPQ overall score, gender, and access to a physician were significantly associated with the total adherence score. Around $24.2 \%$ variation in the adherence score was predicted by these variables. The other variables such as age groups and hypothyroidism education were not significant predictors of the adherence score.

\section{Discussion}

To the best of our knowledge, this is the first study to assess the correlation between illness perception (using the BIPQ score) and medication adherence in hypothyroidism patients in Saudi Arabia. This study included 400 patients with $68.5 \%$ aged below 40 years. We found a significant correlation between poor medication adherence and higher BIPQ score $(p<0.001)$. The mean adherence and overall BIPQ score were 46.2 and 41.4 , respectively.

Similar to our results, a study conducted in Lebanon showed compliance was significantly higher in female hypothyroidism patients. ${ }^{11}$ Conversely, Shakya et al found no association between gender and adherence in patients with hypothyroidism. ${ }^{7}$ In our study, we found no significant association between medication adherence and

Table 3 The Correlation Between Medication Adherence and Illness Perception

\begin{tabular}{|l|l|l|l|l|l|}
\hline Items & $\begin{array}{l}\text { Medication } \\
\text { Compliance }\end{array}$ & Collaboration & Willingness & Acceptance & $\begin{array}{l}\text { Total Score of Medication } \\
\text { Adherence }\end{array}$ \\
\hline Consequences & -.057 & -.039 & -.031 & -.029 & -.048 \\
Timeline & -.003 & 0.069 & 0.043 & 0.036 & 0.048 \\
Personal control & $0.180^{* *}$ & $0.206^{* *}$ & $0.134^{* *}$ & $0.129^{*}$ & $0.203^{* *}$ \\
Treatment control & $0.237^{* *}$ & $0.305^{* *}$ & $0.140^{* *}$ & $0.194^{* *}$ & $0.272^{* *}$ \\
Identity & 0.045 & 0.002 & -.016 & -.049 & -.005 \\
Concerns & -.056 & -.020 & 0.011 & -.089 & -.044 \\
Understanding & $0.169 * *$ & $0.172^{* *}$ & $0.313^{* *}$ & $0.211^{* *}$ & $0.27 I^{* *}$ \\
Emotional response & -.035 & -.058 & -.016 & -.083 & -.058 \\
Total score of BIPQ & $-.144^{* *}$ & $-.152^{* *}$ & $-.126 *$ & $-.159^{* *}$ & $-.180^{* *}$ \\
\hline
\end{tabular}

Notes: ${ }^{*} \mathrm{p}<0.01$ level. ${ }^{*} \mathrm{p}<0.05$ level. 
Table 4 Comparison of Medication Adherence Mean Score in Relation to Socio-Demographic Characteristics of Study Subjects and Patient-Related Factors

\begin{tabular}{|c|c|c|c|c|c|c|c|}
\hline & & $\mathbf{N}$ & $\%$ & $\begin{array}{l}\text { Medication } \\
\text { Adherence Score } \\
\text { Mean }\end{array}$ & $\begin{array}{l}\text { Std. } \\
\text { Deviation }\end{array}$ & $\begin{array}{l}\text { F-valuel } \\
\text { t-value }\end{array}$ & $P$ value \\
\hline Age & $\begin{array}{l}18-40 \text { years } \\
4 I-59 \text { years } \\
60 \text { years and above }\end{array}$ & $\begin{array}{l}273 \\
95 \\
31\end{array}$ & $\begin{array}{l}68.5 \\
23.8 \\
7.8\end{array}$ & $\begin{array}{l}46.20 \\
47.82 \\
41.40\end{array}$ & $\begin{array}{l}0.70 \\
1.00 \\
1.75\end{array}$ & 5.058 & $<0.01$ \\
\hline Gender & $\begin{array}{l}\text { Male } \\
\text { Female }\end{array}$ & $\begin{array}{l}76 \\
321\end{array}$ & $\begin{array}{l}19 \\
80.25\end{array}$ & $\begin{array}{l}42.41 \\
47.10\end{array}$ & $\begin{array}{l}12.90 \\
8.78\end{array}$ & -3.791 & $<0.001$ \\
\hline BMI & $\begin{array}{l}\text { Normal } \\
\text { Overweight } \\
\text { Obese }\end{array}$ & $\begin{array}{l}63 \\
122 \\
197\end{array}$ & $\begin{array}{l}15.8 \\
30.5 \\
49.3\end{array}$ & $\begin{array}{l}45.01 \\
46.66 \\
46.285\end{array}$ & $\begin{array}{l}1.25 \\
0.90 \\
0.711\end{array}$ & 0.586 & 0.557 \\
\hline Do you exercise? & $\begin{array}{l}\text { Yes } \\
\text { No }\end{array}$ & $\begin{array}{l}148 \\
250\end{array}$ & $\begin{array}{l}37 \\
62.5\end{array}$ & $\begin{array}{l}47.32 \\
45.57\end{array}$ & $\begin{array}{l}9.44 \\
10.05\end{array}$ & 1.713 & 0.08 \\
\hline Do you have any comorbidities? & $\begin{array}{l}\text { Yes } \\
\text { No }\end{array}$ & $\begin{array}{l}161 \\
197\end{array}$ & $\begin{array}{l}40.25 \\
49.25\end{array}$ & $\begin{array}{l}45.93 \\
46.26\end{array}$ & $\begin{array}{l}10.07 \\
10.28\end{array}$ & -0.303 & 0.76 \\
\hline Duration of hypothyroidism & $\begin{array}{l}1-5 \text { years } \\
6-10 \text { years } \\
11 \text { years and above }\end{array}$ & $\begin{array}{l}225 \\
64 \\
33\end{array}$ & $\begin{array}{l}56.3 \\
16 \\
8.3\end{array}$ & $\begin{array}{l}46.76 \\
46.01 \\
47.66\end{array}$ & $\begin{array}{l}0.634 \\
1.18 \\
1.65\end{array}$ & 0.345 & 0.709 \\
\hline $\begin{array}{l}\text { Do you follow your condition in the } \\
\text { clinic on regular basis? }\end{array}$ & $\begin{array}{l}\text { Yes } \\
\text { No }\end{array}$ & $\begin{array}{l}313 \\
86\end{array}$ & $\begin{array}{l}78.25 \\
21.5\end{array}$ & $\begin{array}{l}47.51 \\
41.48\end{array}$ & $\begin{array}{l}8.74 \\
12.03\end{array}$ & 5.194 & $<0.0001$ \\
\hline $\begin{array}{l}\text { Have you received an education about } \\
\text { hypothyroidism? }\end{array}$ & $\begin{array}{l}\text { Yes } \\
\text { No }\end{array}$ & $\begin{array}{l}243 \\
156\end{array}$ & $\begin{array}{l}60.75 \\
39\end{array}$ & $\begin{array}{l}47.67 \\
43.95\end{array}$ & $\begin{array}{l}9.64 \\
9.76\end{array}$ & 3.736 & $<0.001$ \\
\hline Do you access your physician easily? & $\begin{array}{l}\text { Yes } \\
\text { No }\end{array}$ & $\begin{array}{l}341 \\
58\end{array}$ & $\begin{array}{l}85.25 \\
14.5\end{array}$ & $\begin{array}{l}47.14 \\
40.73\end{array}$ & $\begin{array}{l}9.17 \\
11.30\end{array}$ & 4.703 & $<0.0001$ \\
\hline $\begin{array}{l}\text { From where do you obtain your } \\
\text { medications? }\end{array}$ & $\begin{array}{l}\text { Free from the clinic } \\
\text { Bought from } \\
\text { pharmacies }\end{array}$ & $\begin{array}{l}341 \\
58\end{array}$ & $\begin{array}{l}85.3 \\
14.5\end{array}$ & $\begin{array}{l}46.37 \\
45.32\end{array}$ & $\begin{array}{l}9.95 \\
9.22\end{array}$ & 0.750 & 0.45 \\
\hline
\end{tabular}

comorbidity. However, a study done in the United States found that adherent patients were less likely to be diagnosed with comorbidity vs non-adherent patients. ${ }^{17}$

Regular follow-up affects adherence since because patients who miss their appointment are more prone to miss instructions from their physicians concerning clinical status, medication dosage, and actions for managing their condition. ${ }^{18}$ In addition, Shakya et al reported that missed appointment to the treating physicians' follow-up visit in the defined time was significantly associated with non-compliance. ${ }^{7}$ In line with

Table 5 The Factors Associated with the Adherence Score in the Multivariate Analysis

\begin{tabular}{|c|c|c|c|c|c|c|c|}
\hline \multirow[t]{2}{*}{ Model } & \multicolumn{2}{|c|}{$\begin{array}{l}\text { Unstandardized } \\
\text { Coefficients }\end{array}$} & \multirow{2}{*}{$\begin{array}{l}\text { Standardized Coefficients } \\
\text { Beta }\end{array}$} & \multirow[t]{2}{*}{ t-value } & \multirow[t]{2}{*}{ p-value } & \multicolumn{2}{|c|}{ 95.0\% Confidence Interval for B } \\
\hline & B & Std. Error & & & & Lower Bound & Upper Bound \\
\hline (Constant) & 58.053 & 1.434 & & 40.478 & 0.000 & 55.233 & 60.872 \\
\hline Following instructions & -9.754 & 1.122 & -.402 & -8.693 & 0.000 & -11.960 & -7.548 \\
\hline Duration of visit & -5.234 & 1.383 & -.179 & -3.784 & 0.000 & -7.953 & -2.515 \\
\hline Total score of BIPQ & -.116 & 0.034 & -.157 & -3.440 & 0.001 & -.182 & -.049 \\
\hline Gender & 3.318 & 1.133 & 0.132 & 2.930 & 0.004 & 1.091 & 5.545 \\
\hline Access to physician & -3.186 & 1.436 & -.113 & -2.219 & 0.027 & -6.010 & -.363 \\
\hline
\end{tabular}


this, the follow-up of the patients showed a strong association with adherence in the current study.

Lack of effective communication between the physician and the patient may contribute to medication nonadherence. ${ }^{19}$ Our results found that having easy access to the physician and following the physician's instructions were positively correlated with a high adherence score. This finding is consistent with another study which showed that the patients' involvement in regular consultation and following the provider's recommendations are the major factors for medication adherence. ${ }^{20}$

Inadequate knowledge of the thyroid gland and associated disorders, and myths and misconceptions have been shown in various studies. A qualitative study of 244 hypothyroid patients revealed that illness misconceptions and faulty practices may contribute to poor adherence. $^{21}$ Our results also support this finding as we found a positive correlation between mean adherence and the patients' understanding of their illness. In our study, we found that patients are more likely to be adherent if they have a higher personal and treatment control belief. This finding is similar to the study by Chen et al which reported that treatment and personal control may indeed be a powerful predictor. $^{22}$ However, in a Nepal study, a statistically significant association was not found between the patients' adherence and their perception of the effectiveness of the medication. ${ }^{7}$

The perception of hypothyroidism was significantly associated with medication adherence in our study similar to previous reports on various illnesses. ${ }^{13,23}$

Though not measured in this study, health literacy has been shown to have a major impact on adherence. ${ }^{24}$ In a Korean study, health literacy was found to be the major predictor of adherence. Also, adequate health literacy was associated with higher adherence rates in studies done in the United States. ${ }^{25,26}$ Therefore, health literacy measures should be considered to improve adherence. The number of doses was not measured in the current study but is believed to influence medication adherence. For instance, a systemic review found that patients who were on once-daily dosing had $13 \%-26 \%$ and $22 \%-41 \%$ more adherent days vs patients on twice-daily and thrice-daily dosing, respectively. ${ }^{27}$ Another review published in 2001 found that patients with fewer dosing regimens had better adherence. ${ }^{28}$

We found that free medication from the clinic was not significantly associated with adherence. This is similar to a study in Sri Lanka on oral medication for diabetes. They did not find a significant difference in medication adherence between the universal-free and fee-paying group.
Conversely, other studies show that a higher medication cost is significantly associated with non-adherence. ${ }^{29,30}$

This is the first study to assess the correlation between medication adherence and illness perception in hypothyroidism patients. The limitations to our study include smaller sample size, region, and the lack of comparative data due to few studies with the same objectives.

\section{Conclusion}

This study found a significant correlation between a high BIPQ overall score with poor medication adherence. There is a need to consider the emotional and cognitive representation of hypothyroidism in patients to improve adherence.

\section{Acknowledgments}

The authors would like to thank the survey patients and the survey team.

\section{Author Contributions}

All authors contributed to data analysis, and drafting and revising the article, and gave final approval of the version to be published. All authors agree to be accountable for all aspects of the work.

\section{Disclosure}

The authors report no conflicts of interest with this work.

\section{References}

1. Chaker L, Bianco AC, Jonklaas J, Peeters RP. Hypothyroidism. Lancet. 2017;390(10101):1550-1562. doi:10.1016/S0140-6736(17)30703-1

2. Vanderpump M, Tunbrldge W, French J, et al. The incidence of thyroid disorders in the community: a twenty-year follow-up of the Whickham Survey. Clin Endocrinol (Oxf). 1995;43(1):55-68. doi:10.1111/j.13652265.1995.tb01894.x

3. Aljabri KSJ, Facharatz AI, Bokhari SA, et al. The frequency of hypothyroidism in saudi community-based hospital: a retrospective single centre study. Trends Diabetes Metab. 2019;2(1). doi:10.15761/ TDM. 1000107

4. Jonklaas J, Bianco AC, Bauer AJ, et al. Guidelines for the treatment of hypothyroidism: prepared by the american thyroid association task force on thyroid hormone replacement. Thyroid. 2014;24(12):16 70-1751. doi:10.1089/thy.2014.0028

5. Yach D, Bengoa R. WHO Adherence Project: Toward Policies for Action. 2001.

6. Briesacher BA, Andrade SE, Fouayzi H, Chan KA. Comparison of drug adherence rates among patients with seven different medical conditions. Pharmacotherapy. 2008;28(4):437-443. doi:10.1592/ phco.28.4.437

7. Shakya Shrestha S, Risal K, Shrestha R, Bhatta R. Medication adherence to levothyroxine therapy among hypothyroid patients and their clinical outcomes with special reference to thyroid function parameters. Kathmandu Univ Med J. 2018;62(2):129-137. 
8. Crilly M, Esmail A. Randomised controlled trial of a hypothyroid educational booklet to improve thyroxine adherence. Br J Gen Pract. 2005;55(514):362-368.

9. Ross S, Walker A, MacLeod MJ. Patient compliance in hypertension: role of illness perceptions and treatment beliefs. J Hum Hypertens. 2004;18(9):607-613. doi:10.1038/sj.jhh.1001721

10. Christiani Y, Byles J, Tavener M, Dugdale P. Assessing socioeconomic inequalities of hypertension among women in Indonesia's major cities. J Hum Hypertens. 2015;29(11):683-688. doi:10.1038/ jhh.2015.8

11. Helou E, Hallit S Awada S. Adherence to levothyroxine among patients with hypothyroidism in Lebanon. East Mediterr Health J. ;201925.

12. Taibanguay N, Chaiamnuay S, Asavatanabodee P, Narongroeknawin P. Effect of patient education on medication adherence of patients with rheumatoid arthritis: a randomized controlled trial. Patient Prefer Adherence. 2019;13:119-129. doi:10.2147/PPA.S192008

13. Miyazaki M, Nakashima A, Nakamura Y, et al. Association between medication adherence and illness perceptions in atrial fibrillation patients treated with direct oral anticoagulants: an observational cross-sectional pilot study. PLoS One. 2018;13(9):e0204814. doi:10.1371/journal.pone.0204814

14. Kucukarslan SN. A review of published studies of patients' illness perceptions and medication adherence: lessons learned and future directions. Res Social Adm Pharm. 2012;8(5):371-382. doi:10.1016/ j.sapharm.2011.09.002

15. Alsubeeh NA, Alsharafi AA, Ahamed SS, Alajlan A. Treatment adherence among patients with five dermatological diseases and four treatment types - a cross-sectional study. Patient Prefer Adherence. 2019;13:2029-2038. doi:10.2147/PPA.S230921

16. Saarti S, Jabbour H, El Osta N, Hajj A, Khabbaz LR. Cross-cultural adaptation and psychometric properties of an Arabic language version of the brief illness perception questionnaire in lebanon. Libyan $J$ Med. 2016;11(1):31976. doi:10.3402/ljm.v11.31976

17. Hepp Z, Lage MJ, Espaillat R, Gossain VV. The association between adherence to levothyroxine and economic and clinical outcomes in patients with hypothyroidism in the US. J Med Econ. 2018;21 (9):912-919. doi:10.1080/13696998.2018.1484749

18. Nwabuo CC, Dy SM, Weeks K, Young JH. Factors associated with appointment non-adherence among African-Americans with severe, poorly controlled hypertension. PLoS One. 2014;9(8):e103090. doi:10.1371/journal.pone.0103090
19. Brown MT, Bussell JK. Medication adherence: WHO cares? Mayo Clin Proc. 2011;86(4):304-314. doi:10.4065/mcp.2010.0575

20. Bosworth HB, Granger BB, Mendys P, et al. Medication adherence: a call for action. Am Heart J. 2011;162(3):412-424. doi:10.1016/j. ahj.2011.06.007

21. Kumar P, Khandelwal D, Mittal S, et al. Knowledge, awareness, practices and adherence to treatment of patients with primary hypothyroidism in Delhi. Indian J Endocrinol Metab. 2017;21 (3):429-433. doi:10.4103/ijem.IJEM_49_17

22. Chen SL, Tsai JC, Lee WL. The impact of illness perception on adherence to therapeutic regimens of patients with hypertension in Taiwan. J Clin Nurs. 2009;18(15):2234-2244. doi:10.1111/j.13652702.2008.02706.x

23. Rajpura J, Nayak R. Medication adherence in a sample of elderly suffering from hypertension: evaluating the influence of illness perceptions, treatment beliefs, and illness burden. J Manag Care Pharm. 2014;20(1):58-65. doi:10.18553/jmcp.2014.20.1.58

24. Lee YM, Yu HY, You MA, Son YJ. Impact of health literacy on medication adherence in older people with chronic diseases. Collegian. 2017;24(1):11-18. doi:10.1016/j.colegn.2015.08.003

25. Lor M, Koleck TA, Bakken S, Yoon S, Dunn Navarra AM. Association between health literacy and medication adherence among hispanics with hypertension. $J$ Racial Ethn Health Disparities. 2019;6(3):517-524. doi:10.1007/s40615-018-00550-z

26. Zhang NJ, Terry A, McHorney CA. Impact of health literacy on medication adherence: a systematic review and meta-analysis. Ann Pharmacother. 2014;48(6):741-751. doi:10.1177/1060028014526562

27. Saini SD, Schoenfeld P, Kaulback K, Dubinsky MC. Effect of medication dosing frequency on adherence in chronic diseases. $\mathrm{Am}$ J Manag Care. 2009;15(6):e22-e33.

28. Claxton AJ, Cramer J, Pierce C. A systematic review of the associations between dose regimens and medication compliance. Clin Ther. 2001;23(8):1296-1310. doi:10.1016/S0149-2918(01)80109-0

29. Rwegerera GM. Adherence to anti-diabetic drugs among patients with type 2 diabetes mellitus at muhimbili national hospital, dar es salaam, tanzania- a cross-sectional study. Pan Afr Med J. 2014;17:252. doi:10.11604/pamj.2014.17.252.2972

30. Adisa R, Fakeye TO, Fasanmade A. Medication adherence among ambulatory patients with type 2 diabetes in a tertiary healthcare setting in southwestern Nigeria. Pharm Pract (Granada). 2011;9 (2):72-81. doi:10.4321/S1886-36552011000200003
Patient Preference and Adherence

\section{Publish your work in this journal}

Patient Preference and Adherence is an international, peer-reviewed, open access journal that focuses on the growing importance of patient preference and adherence throughout the therapeutic continuum. Patient satisfaction, acceptability, quality of life, compliance, persistence and their role in developing new therapeutic modalities and compounds to optimize clinical outcomes for existing disease states are major areas of interest for the journal. This journal has been accepted for indexing on PubMed Central. The manuscript management system is completely online and includes a very quick and fair peer-review system, which is all easy to use. Visit http:// www.dovepress.com/testimonials.php to read real quotes from published authors. 